\title{
Modification of Static Bending Strength Properties of Eucalyptus grandis Heat-Treated Wood
}

\author{
Pedro Henrique Gonzalez de Cademartori ${ }^{a *}$, Eduardo Schneid ${ }^{b}$,Darci Alberto Gatto ${ }^{c}$, \\ Rafael Beltrame ${ }^{\mathrm{c}}$, Diego Martins Stangerlin ${ }^{\mathrm{d}}$ \\ ${ }^{a}$ College of Materials Engineering, Technology Development Center - CDTec, \\ Federal University of Pelotas - UFPel, CEP 96010-000, Pelotas, RS, Brazil \\ ${ }^{\mathrm{b}}$ College of Forest Engineering, Department of Forest Science, Rural Science Center, \\ Federal University of Santa Maria - UFSM, CEP 97105-900, Santa Maria, RS, Brazil \\ ${ }^{\mathrm{C}}$ College of Wood Industrial Engineering, Federal University of Pelotas - UFPel, \\ CEP 96010-290, Pelotas, RS, Brazil \\ ${ }^{\mathrm{d} I n s t i t u t e}$ of Agricultural and Environmental Sciences, Forest Engineering, \\ Federal University of Mato Grosso - UFMT, CEP 78557-267, Sinop, MT, Brazil
}

Received: March 31, 2012; Revised: June 6, 2012

\begin{abstract}
The present study describes the effect of thermal rectification on physical and mechanical properties of Eucalyptus grandis wood at different levels of temperature and time. Samples of Eucalyptus grandis wood $(10 \times 10 \times 200 \mathrm{~mm})$ were heat-treated at $180,200,220$ and $240{ }^{\circ} \mathrm{C}$ during 4 and 8 hours. The mechanical properties of heat-treated and untreated samples were determined by static bending tests. The physical properties were determined by weight loss and swelling tests. The results showed that modulus of elasticity, modulus of rupture, weight loss, volumetric swelling and linear swelling were affected significantly by the thermal rectification. However, the length of exposure influenced just weight loss, while the temperature influenced all the studied properties of heat-treated wood. More significant modifications with treatments at a temperature of $200{ }^{\circ} \mathrm{C}$ or higher were found in the properties of heat-treated wood.
\end{abstract}

Keywords: heat treatment, thermal rectification, wood technology

\section{Introduction}

Wood is a lignocellulosic material, which presents commercial and industrial limitations when used incorrectly. For this reason, many processes were developed over the years to reduce the physical and biological degradation of wood, as in the case of the thermal rectification.

The thermal rectification exposes the wood to high temperatures in order to modify its structure. This process occurs at temperatures between 180 and $260{ }^{\circ} \mathrm{C}$ because temperatures below $140^{\circ} \mathrm{C}$ cause insignificant modifications in the structure of the material, whereas temperatures over $260{ }^{\circ} \mathrm{C}$ result in undesirable degradation ${ }^{1}$.

Moreover, the thermal rectification is a way to substitute the use of chemical products to protect the wood from biodegradation and, at the same time, a way to modify physical properties of this material, mainly hygroscopicity and anisotropy. Some authors ${ }^{2,3}$ reported that heat treatment at $200{ }^{\circ} \mathrm{C}$ reduced the hygroscopicity of wood and modified its moisture equilibrium content to $4-5 \%$ and increased of around $50 \%$ in the dimensional stability of wood with heat treatments between 180 and $200{ }^{\circ} \mathrm{C}$.

On the other hand, the thermal rectification reduces the mechanical properties of wood and along with weight loss, it

*e-mail: pedrocademartori@gmail.com can consequently limit the structural use of pieces of wood. In addition, the authors state that the level of reduction in the mechanical properties depends on the species and process conditions ${ }^{4}$.

Taking these facts into consideration, the present study aimed to evaluate the physical and mechanical behavior of Eucalyptus grandis wood heat-treated at different levels of temperature and time.

\section{Material and Methods}

\subsection{Test samples}

Sixteen Eucalyptus grandis trees (17 years old) from homogeneous population were harvested in the north coast of Rio Grande do Sul state, in the south of Brazil (30 14'09.73' ' S and 50 19' 55.07' O).

The first $\log (3.15 \mathrm{~m}$ length) of each tree was cut. Then, 80 samples of size $10 \mathrm{~mm} \times 10 \mathrm{~mm} \times 200 \mathrm{~mm}$ (radial $\times$ tangential $\times$ longitudinal) were prepared, all of them with good orientation and made only of heartwood with absence of flaws. 


\subsection{Heat treatment}

The samples were then placed in a climatic chamber ( $20{ }^{\circ} \mathrm{C}$ and $65 \% \mathrm{RH}$ ) to stabilize the moisture content in $12 \%$, which was the initial condition for the heat treatment of wood.

After the stabilization, the samples were heat-treated in an electric kiln, without forced air circulation at 180, 200, 220 and $240{ }^{\circ} \mathrm{C}$ during 4 and 8 hours, and one treatment was the reference (untreated and remained in the climatic chamber). The rate of heating was $2{ }^{\circ} \mathrm{C} / \mathrm{min}$ and the control of the temperature was realized with two thermometers located at the top of the electric kiln.

Ten replicates were used for each treatment condition regarding length of time and temperature.

After the treatments, the samples were then placed in climatic chamber $\left(20{ }^{\circ} \mathrm{C}\right.$ and $\left.65 \% \mathrm{RH}\right)$ until the physicomechanical evaluation.

\subsection{Mechanical properties}

The mechanical properties were characterized in a universal machine with capacity of $300 \mathrm{kN}$. The static bending tests were performed in a three-point bending apparatus with a span length of $140 \mathrm{~mm}$ and cross-head of $1.30 \mathrm{~mm} / \mathrm{min}$.

The modulus of elasticity (MOE) and the modulus of rupture (MOR) were determined based on the rules of the American Society for Testing and Materials - ASTM D $143-94^{5}$.

\subsection{Physical properties}

The weight loss was measured from the weight of the samples before and after the thermal rectification (Equation 1).

$W L=\frac{M_{B H}-M_{A H}}{M_{B H}} \times 100$

where: $\mathrm{WL}=$ weight loss $(\%) ; \mathrm{M}_{\mathrm{BH}}=$ weight before the thermal rectification $(\mathrm{g}) ; \mathrm{M}_{\mathrm{AH}}=$ weight after the thermal rectification $(\mathrm{g})$.

The determination of the dimensional stability was performed in samples with dimensions $1 \times 1 \times 4 \mathrm{~cm}$, which were obtained from the original samples $(1 \times 1 \times 20 \mathrm{~cm})$.

The samples were immersed in water for 24 hours and later dried in an electric kiln at $103 \pm 2{ }^{\circ} \mathrm{C}$ until they reached constant weight. The physical properties of swelling (volumetric and radial/tangential linear) were determined with the use of Equations 2 and 3.

$a_{v}=\frac{V u-V o}{V o} \times 100$

$a_{l}=\frac{L u-L o}{L o} \times 100$

where: $\alpha_{v}=$ volumetric swelling $(\%) ; \mathrm{Vu}=$ volume of samples after immersion in water $\left(\mathrm{cm}^{3}\right) ; \mathrm{Vo}=$ dried volume at $0 \%\left(\mathrm{~cm}^{3}\right) ; \alpha_{1}=$ linear swelling (radial and tangential) $(\%)$; $\mathrm{Lu}=$ linear dimension after immersion in water (radial and tangential) $(\mathrm{cm}) ;$ Lo $=$ dried linear dimension (radial and tangential) at $0 \%$ of moisture content $(\mathrm{cm})$.

\subsection{Data analysis}

The collected data were assessed using the analysis of variance $(\mathrm{p}<0.05)$. When the null hypothesis was rejected, the average values were compared with Tukey Test at the level of significance of $5 \%$.

\section{Results and Discussion}

Table 1 and Figure 1 show the results and behavior of mechanical properties of Eucalyptus grandis heat-treated wood. In general, the thermal rectifications reduced the mechanical properties significantly. However, the length of the treatment did not have significant influence on the mechanical properties, unlike what happened regarding the temperature.

The modulus of rupture showed reduction between 21.91 (180-4) and $49.90 \%$ (240-8). The highest average value for the modulus of rupture was observed in the untreated samples. However, the lowest average value of MOR was observed in the treatment with the most drastic conditions, specifically at $240{ }^{\circ} \mathrm{C}$ for 8 hours.

The modulus of elasticity also decreased with the increase in the conditions of treatment (length of time and temperature), except for the treatment at $180^{\circ} \mathrm{C}$ for 8 hours, which showed a small increase in the MOE. The variation (between 2.21 and 19.86\%) was significant, but lower than the one found for the MOR.

Many studies have shown small increase in the MOE of wood treated for short periods, since the reduction of this property depends on the temperature and the conditions of the process ${ }^{1}$.

Other study ${ }^{6}$ observed a reduction of around $52.3 \%$ in the MOR of Eucalyptus grandis wood heat-treated at $220{ }^{\circ} \mathrm{C}$ during 2.5 hours. The modulus of rupture of their untreated samples (69 MPa) was lower than the one of the untreated samples of this study (82.77 MPa). Moreover, the authors verified an increase in the MOE, except for the treatment at $220^{\circ} \mathrm{C}$.

As in the present study, the reduction of the modulus of elasticity was also observed for the Pinus brutia wood heat-treated at 130,180 and $230{ }^{\circ} \mathrm{C}$ for 2 and 8 hours $^{7}$ and Pinus nigra and Abies bornmülleriana heat-treated by the ThermoWood process 8 .

Visually, the intensity of internal cracks formation was high, mainly in the samples treated at 220 and $240{ }^{\circ} \mathrm{C}$. The same situation was observed for many studies ${ }^{9-11}$. The formation of internal cracks in the wood is closely associated to the cell collapse ${ }^{9}$.

During the static bending tests, the samples of treatments at 220 and $240{ }^{\circ} \mathrm{C}$ showed more abrupt rupture than the other treatments. This fact in the present study is an evidence of the influence of internal cracks in the mechanical properties.

Table 2 and Figure 2 a present the average values of weight loss (WL) and dimensional stability of Eucalyptus grandis heat-treated wood.

The weight loss increased with increasing in temperature and length of the thermal rectification. The highest decrease of weight was at $240{ }^{\circ} \mathrm{C}$ for 8 hours, the treatment with the most drastic conditions. This property (WL) was influenced by the length of exposure. The treatments at 200, 220 and $240{ }^{\circ} \mathrm{C}$ showed significant difference when the wood was treated for 4 and 8 hours (Table 2). 
Table 1. Effect of thermal rectification on the mechanical properties of Eucalyptus grandis wood.

\begin{tabular}{cccc}
\hline T $\left({ }^{\circ} \mathbf{C}-\mathbf{h}\right)$ & $\mathbf{F}_{\text {max }}(\mathbf{N})$ & MOR $(\mathbf{M P a})$ & MOE $(\mathbf{M P a})$ \\
\hline Untreated & $378.70(48.35)^{\mathrm{c}}$ & $82.77(12.12)^{\mathrm{c}}$ & $11496.8(1734.13)^{\mathrm{b}}$ \\
$180-4$ & $374.91(70.24)^{\mathrm{c}}$ & $64.63(14.91)^{\mathrm{bc}}$ & $11242(2044.3)^{\mathrm{ab}}$ \\
$180-8$ & $359.81(71.93)^{\mathrm{c}}$ & $63.20(11.27)^{\mathrm{b}}$ & $11498.6(1252.58)^{\mathrm{b}}$ \\
$200-4$ & $320.57(100.02)^{\mathrm{bc}}$ & $54.30(17.36)^{\mathrm{ab}}$ & $10081.0(1332.02)^{\mathrm{ab}}$ \\
$200-8$ & $294.20(90.43)^{\mathrm{abc}}$ & $50.93(15.03)^{\mathrm{ab}}$ & $9848.22(1439.43)^{\mathrm{ab}}$ \\
$220-4$ & $239.99(90.77)^{\mathrm{ab}}$ & $45.63(14.37)^{\mathrm{ab}}$ & $9819.09(1998.21)^{\mathrm{ab}}$ \\
$220-8$ & $232.13(77.33)^{\mathrm{ab}}$ & $42.04(14.44)^{\mathrm{a}}$ & $9673.38(1312.28)^{\mathrm{ab}}$ \\
$240-4$ & $232.35(47.53)^{\mathrm{ab}}$ & $42.18(10.06)^{\mathrm{a}}$ & $9123.73(1681)^{\mathrm{a}}$ \\
$240-8$ & $214.10(68.54)^{\mathrm{a}}$ & $42.31(14.55)^{\mathrm{a}}$ & $9212.8(1943.41)^{\mathrm{a}}$ \\
& $\mathrm{F}=12,89^{* *}$ & $\mathrm{~F}=18.18^{* *}$ & $\mathrm{~F}=5,78^{* *}$ \\
ANOVA & $\mathrm{p}<0,0000$ & $\mathrm{p}<0,0000$ & $\mathrm{p}<0,0000$ \\
\hline
\end{tabular}

$*$ Significant at confidence level of $5 \%$; * Significant at confidence level of $1 \%$; Values in parentheses correspond to the standard deviation; $\mathrm{F}_{\max }=$ Maximum force of rupture at static bending; $\mathrm{MOR}=$ modulus of rupture at static bending; $\mathrm{MOE}=$ modulus of elasticity at static bending; $\mathrm{T}=$ treatment (temperature-time).

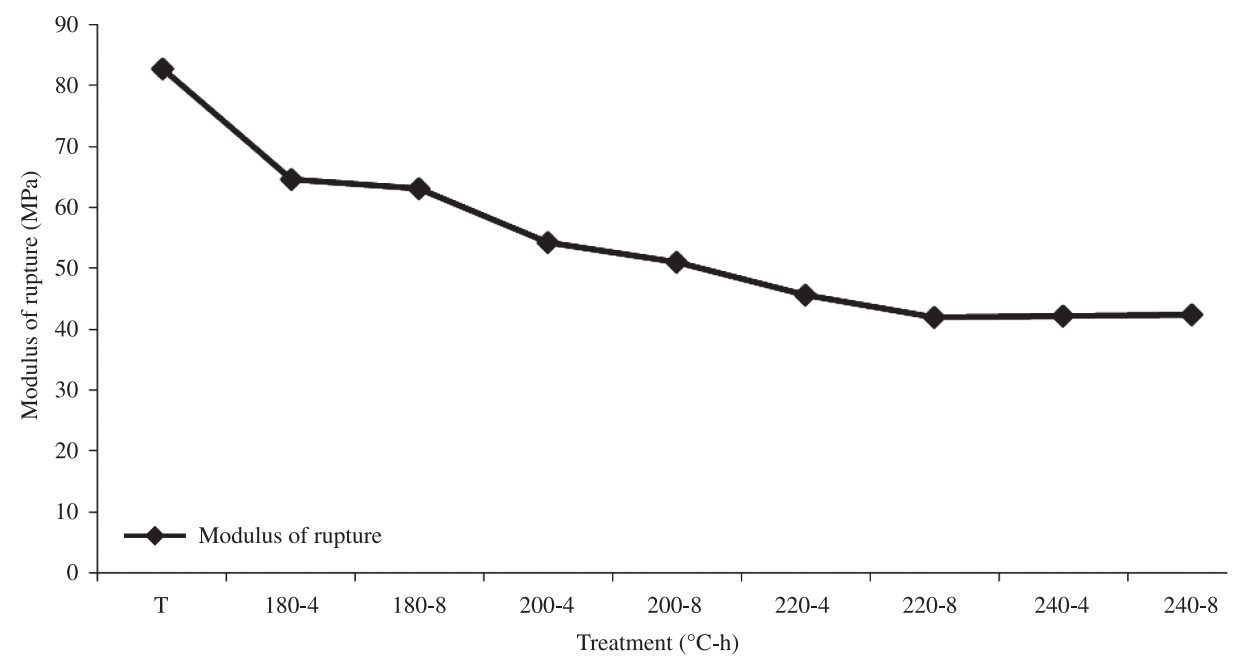

(a)

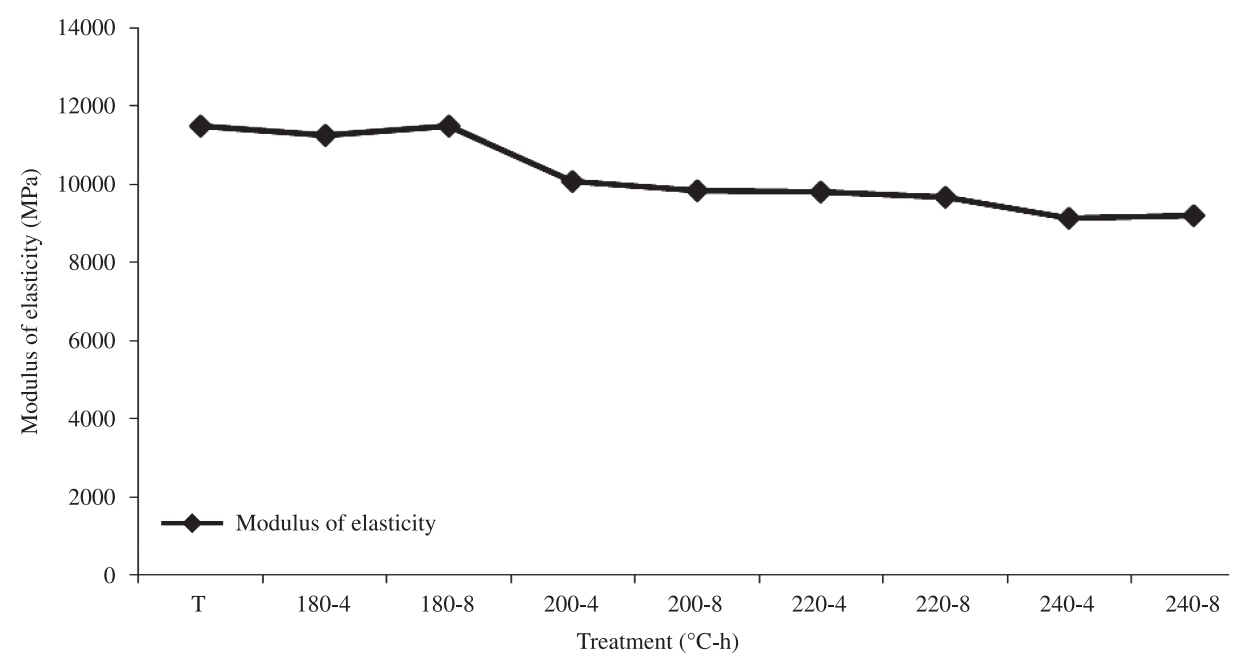

(b)

Figure 1. Modulus of rupture (a) and modulus of elasticity (b) as a function of the time and temperature of Eucalyptus grandis heat-treated wood. 
Table 2. Effect of thermal rectification on the weight loss and dimensional stability of Eucalyptus grandis wood.

\begin{tabular}{ccccc}
\hline \multirow{2}{*}{ T $\left({ }^{\circ} \mathbf{C}-\mathbf{h}\right)$} & WL $(\boldsymbol{\%})$ & $\beta_{\mathrm{v}}(\boldsymbol{\%})$ & \multicolumn{2}{c}{$\beta_{\mathbf{l}}(\boldsymbol{\%})$} \\
\cline { 4 - 5 } & & & Radial $^{\text {Tangential }}$ \\
\hline Untreated & - & $3.64(1.17)^{\mathrm{d}}$ & $1.31(031)^{\mathrm{d}}$ & $2.10(0.36)^{\mathrm{c}}$ \\
$180-4$ & $12.74(1.44)^{\mathrm{a}}$ & $3.39(0.75)^{\mathrm{cd}}$ & $1.25(0.34)^{\mathrm{cd}}$ & $2.05(0.44)^{\mathrm{c}}$ \\
$180-8$ & $12.39(0.36)^{\mathrm{a}}$ & $3.05(0.56)^{\mathrm{bcd}}$ & $1.21(0.20)^{\mathrm{bcd}}$ & $1.84(0.23)^{\mathrm{c}}$ \\
$200-4$ & $14.89(0.26)^{\mathrm{b}}$ & $2.17(0.44)^{\mathrm{a}}$ & $0.94(0.24)^{\mathrm{abc}}$ & $1.33(0.27)^{\mathrm{b}}$ \\
$200-8$ & $17.38(0.62)^{\mathrm{c}}$ & $2.17(0.43)^{\mathrm{ab}}$ & $0.89(0.29)^{\mathrm{ab}}$ & $1.19(0.16)^{\mathrm{ab}}$ \\
$220-4$ & $18.27(1.44)^{\mathrm{c}}$ & $2.21(0.33)^{\mathrm{abc}}$ & $0.85(0.14)^{\mathrm{a}}$ & $1.18(0.15)^{\mathrm{ab}}$ \\
$220-8$ & $20.17(1.55)^{\mathrm{d}}$ & $2.17(0.68)^{\mathrm{ab}}$ & $0.83(0.25)^{\mathrm{a}}$ & $1.12(0.36)^{\mathrm{ab}}$ \\
$240-4$ & $20.28(0.87)^{\mathrm{d}}$ & $1.93(0.70)^{\mathrm{a}}$ & $0.83(0.22)^{\mathrm{a}}$ & $1.10(0.26)^{\mathrm{ab}}$ \\
$240-8$ & $22.51(1.61)^{\mathrm{e}}$ & $1.63(0.67)^{\mathrm{a}}$ & $0.61(0.30)^{\mathrm{a}}$ & $0.91(0.30)^{\mathrm{a}}$ \\
ANOVA & $\mathrm{F}=209.02^{* *}$ & $\mathrm{~F}=15.44^{* *}$ & $\mathrm{~F}=12.80^{* *}$ & $\mathrm{~F}=36.57 * *$ \\
\end{tabular}

*Significant at confidence level of 5\%; **Significant at confidence level of $1 \%$; Values in parentheses correspond to the standard deviation; WL $=$ weight loss (\%); $\alpha_{v}=$ volumetric swelling; $\alpha_{1}=$ linear swelling; $\mathrm{T}=$ treatment (temperature-time).

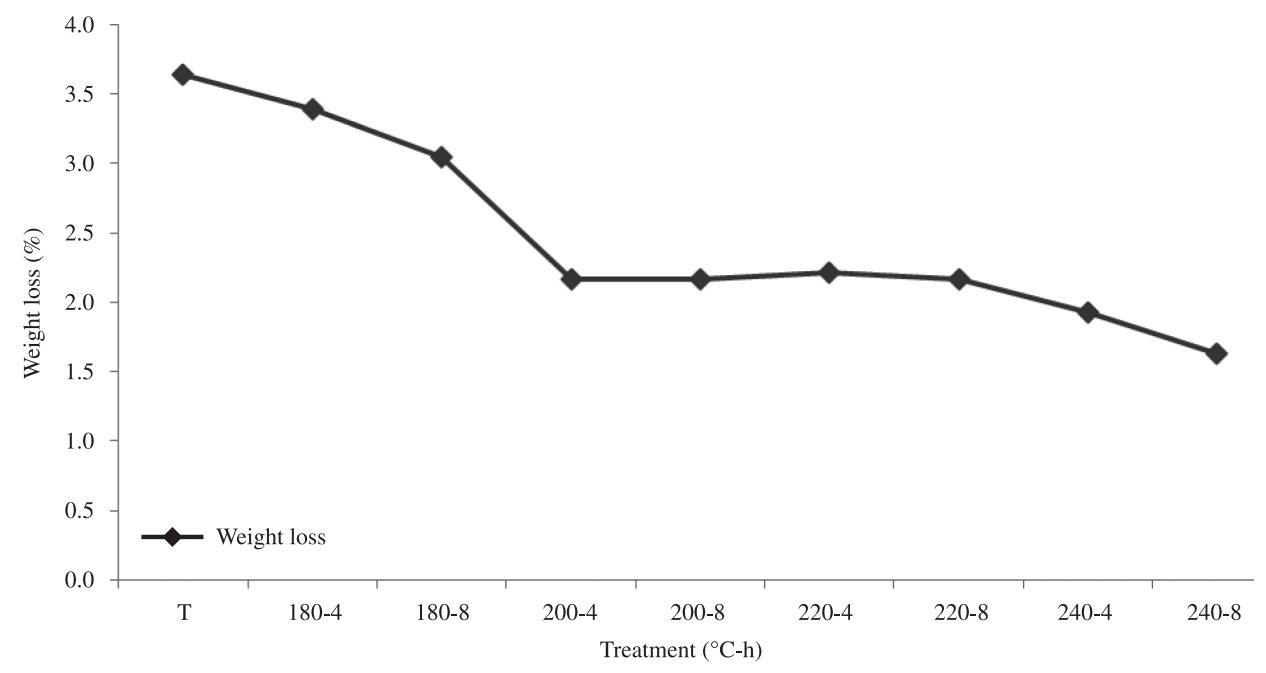

(a)

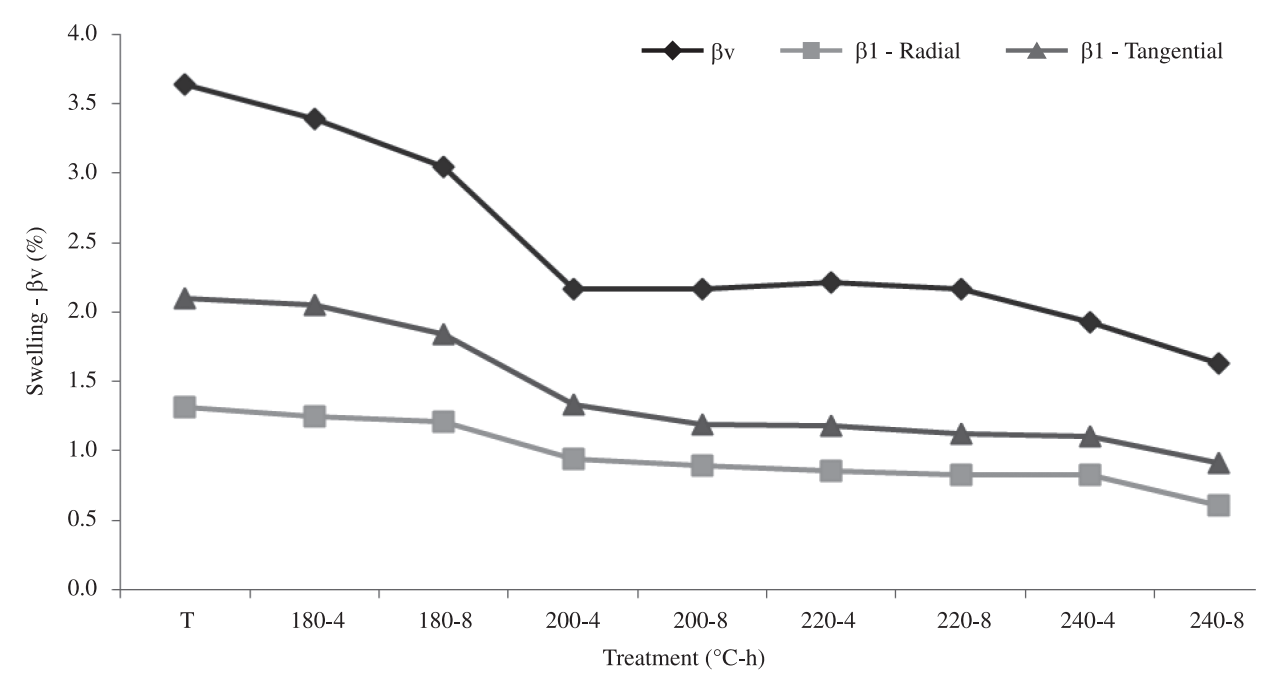

(b)

Figure 2. Weight loss (a) and swelling (b) behavior as a function of the temperature and the time of Eucalyptus grandis heat-treated wood. 
The weight loss is a common characteristic of heat-treated wood and was identified in many studies ${ }^{4,11-14}$. In other research, the authors ${ }^{15}$ reported lower average weight loss for Eucalyptus globulus wood heat-treated with the presence of pressure and steam than in the present study. They found values of weight loss between 3.7 and $14.5 \%$ at 190,200 and $210^{\circ} \mathrm{C}$ for 2,6 and 12 hours.

The level of degradation of the wood depends on process conditions, such as temperature, length of exposure and atmosphere. On the one hand, high rates of weight loss can be observed in thermal rectification with closed systems, always considering temperature and atmosphere ${ }^{1}$. On the other hand, low rates of weight loss can be observed in heat treatments with the presence of vacuum or humidity.

The thermal rectification increases the degree of repellence to water and, in general, showed to be inversely proportional to the increase in temperature and length of exposure.

The average values of volumetric swelling of the heat-treated samples decreased between 6.8 and $55.21 \%$ in relation to the untreated samples. Likewise, rates of linear swelling (radial and tangential) showed an increase of dimensional stability.

The rates of volumetric and linear (radial and tangential) swelling showed significant reduction with thermal rectification at $200{ }^{\circ} \mathrm{C}$ for 4 hours, and remained constant until the treatment at $240{ }^{\circ} \mathrm{C}$ for 8 hours (Figure 2b). Others researchers ${ }^{6}$ also studied the behavior of Eucalyptus grandis and reported a similar decrease in volumetric swelling $(53.3 \%)$.

\section{References}

1. Hill CAS. Wood modification: Chemical, thermal and other processes. Chichester: Wiley; 2006. http://dx.doi. org/10.1002/0470021748

2. Vernois M. Heat treatment of wood in France: state of the art. In: Rapp AO, editor. Review on Heat Treatments of Wood. In: Proceedings of the Special Seminar: Environmental Optimisation of Wood Protection; 2001; Antibes, France. Cost Action E 22; 2001. p. 39-46.

3. Jermannaud A, Duchez L and Guyonnet R. Wood retification in France: an industrial process of heat treatment producing lumber with improved resistance to decay. In: Proceedings of the Enhancing the durability of lumber and engineered wood products; 2002; United States. Forest Products Society; 2002. p. 121-122.

4. Borrega M and Kärenlampi P. Mechanical behavior of heat-treated spruce (Picea abies) wood at constant moisture content and ambient humidity. Holz Roh-Werkst. 2008; 66:63-69. http://dx.doi.org/10.1007/s00107-007-0207-3

5. American Society for Testing and Materials - ASTM. D143-94: Standard methods of testing small clear samples of timber. In: American Society for Testing and Materials - ASTM. Annual Book of ASTM. Philadelphi: ASTM; 1994.

6. Calonego FW, Severo ETD and Ballarin AW. Physical and mechanical properties of thermally modified wood from E. grandis. European Journal of Wood and Wood Products. 2011; 70(4):453-460. http://dx.doi.org/10.1007/ s00107-011-0568-5
Hemicellulose is the most hygroscopic component of wood $^{1}$ and its decomposition has intense relation with the increase in dimensional stability and water repellence of heat-treated wood at high temperatures ${ }^{16-19}$. The degradation of hemicellulose is predominant in temperatures below $200{ }^{\circ} \mathrm{C}^{20}$.

\section{Conclusions}

The thermal rectification affected significantly the physicomechanical properties of E. grandis wood.

The MOR and MOE showed to be inversely proportional to the increase in the temperature of the process. On the other hand, the thermal rectification increases the capacity of water repellence.

The length of exposure shown to influence just weight loss. On the other hand, the temperature influenced all the studied properties as well as in relation to the untreated samples.

In general, when compared with the untreated samples, the properties of the heat-treated samples ones presented more significant modifications with treatments at $200{ }^{\circ} \mathrm{C}$ or higher.

\section{Acknowledgements}

The authors wish to thank CNPq (National Counsel of Technological and Scientific Development) and CAPES (Coordination for Improvement of Higher Education Personnel) for the financial support.

7. Ates $\mathrm{S}$, Akyildiz $\mathrm{MH}$ and Ozdemir H. Effects of heat treatment on calabrian pine (Pinus brutia Ten.) wood. Bioresources. 2009; 4(3):1032-1043.

8. Kol HS. Characteristics of heat-treated Turkish pine and fir wood after ThermoWood processing. Journal of Environmental Biology. 2010; 31(6):1007-1011. PMid:21506490.

9. Johansson D. Drying and heat treatment of wood: Influences on internal checking. In: Proceedings of the 3rd Nordic Drying Conference; 2005; Sweden. Karlstad University; 2005.

10. Boonstra MJ, Rijsdijk JF, Sander C, Kegel E, Tjeedersma $\mathrm{B}$, Militz $\mathrm{H}$ et al. Microstructural and physical aspects of heat treated wood. Part 2. Hardwoods. Maderas. Ciencia y tecnología. 2006; 8:209-17.

11. Garcia RA, Carvalho AM, Latorraca JVF, Matos JLM, Santos WA and Silva RFM. Nondestructive evaluation of heat-treated Eucalyptus grandis Hill ex Maiden wood using stress wave method. Wood Science and Technology. 2010; 46:41-52. http:// dx.doi.org/10.1007/s00226-010-0387-6

12. Borrega M and Kärenlampi PP. Hygroscopicity of heat-treated Norway spruce (Picea abies) wood. European Journal of Wood and Wood Products. 2010; 68:233-235. http://dx.doi. org/10.1007/s00107-009-0371-8

13. Metsä-Kortelainen S, Antikainen $T$ and Viitaniemi P. The water absorption of sapwood and heartwood of Scots pine and Norway spruce heat-treated at $170{ }^{\circ} \mathrm{C}, 190{ }^{\circ} \mathrm{C}, 210{ }^{\circ} \mathrm{C}$ and $230^{\circ}$ C. Holz, Roh-Werkst. 2006; 64:192-197.

14. Phuong LX, Shida S and Saito Y. Effect of heat treatment on brittleness of Styrax tonkinensis wood. Journal of Wood Science. 2007; 53:181-186. http://dx.doi.org/10.1007/ s10086-006-0841-0 
15. Esteves B, Marques AV, Domingos I and Pereira H. Influence of steam heating on the properties of pine (Pinus pinaster) and eucalypt (Eucalyptus globulus) wood. Wood Science and Technology. 2007; 41:193-207. http://dx.doi.org/10.1007/ s00226-006-0099-0

16. Seborg RM, Tarkow $\mathrm{H}$ and Stamm AJ. Effect of heat upon the dimensional stabilization of wood. Journal of Forest Product Research Society. 1953; 3:59-67.

17. Hillis WE. High temperature and chemical effects on wood stability. Wood Science and Technology. 1984; 18:281-293. http://dx.doi.org/10.1007/BF00353364
18. Evans P. Emerging Technologies in wood protection. Forest Products Journal. 2003; 53:14-21.

19. Dubey MK, Pang S and Walker J. Effect of oil heating age on colour and dimensional stability of heat treated Pinus radiata. European Journal of Wood and Wood Products. 2011; 69:255-262. http://dx.doi.org/10.1007/ s00107-010-0431-0

20. Sundqvist B. Colour change and acid formation in wood during heating. [Thesis]. Sweden: Lulea University of Technology; 2004.

\section{Erratum}

Manuscript: Modification of Static Bending Strength Properties of Eucalyptus grandis Heat-Treated Wood

Publication: Materials Research. 2012; 15(6): 922-927.

DOI: $10.1590 / \mathrm{S} 1516-14392012005000136$

On page 923 of the original publication, in the results and discussion, in the last paragraph of this page, first and second line, where is written "The weight loss was inversely proportional to the increase in temperature and length of the thermal rectification." should be read "The weight loss increased with increasing in temperature and length of the thermal rectification."

On page 926 of the original publication, in the conclusions, second paragraph, first and second line, where is written "The MOR, MOE and weight loss showed to be inversely proportional to the increase in the temperature of the process." should be read "The MOR and MOE showed to be inversely proportional to the increase in the temperature of the process." 